\title{
LA GREGUERÍA COMO “CÉLULA BELLA": UN CORRELATO DE LA TEORÍA ORTEGUIANA
}

\author{
THE GREGUERÍA AS A "CELL OF BEAUTY": \\ A CORRESPONDENCE OF ORTEGA'S THEORY
}

\author{
Celia María GUTIÉRREZ VÁZQUEZ \\ celiagv171@hotmail.com
}

Resumen: El presente artículo ofrece un análisis dialógico de la teoría estética orteguiana en relación con la práctica literaria de Ramón Gómez de la Serna, partiendo de una serie de greguerías marcadas por el filósofo en dos ejemplares de su biblioteca personal. Además de establecer vínculos imprescindibles en el concepto de estilo de ambos autores, se analizan las greguerías como ejemplo práctico y metaliterario de la metáfora y el signo estético en Ortega. La perspectiva dialógica del estudio contribuye a hacer patente la actualidad de la teoría orteguiana y pretende aportar nuevas perspectivas a la controvertida idea de deshumanización del arte.

Palabras clave: José Ortega y Gasset. Ramón Gómez de la Serna. Greguería. Metáfora. Deshumanización del arte.

Abstract: The present work offers a dialogic study between the aesthetic theory of Ortega y Gasset and the literary practice of Ramón Gómez de la Serna, based on a group of greguerías highlighted by the philosopher in two copies found at his personal library. Besides establishing essential conexions between both notions of style, we analyse the greguerías as a practical example and metaliterature of orteguian metaphor and his theory of aesthetic sign. The dialectical perspective of this study reveals that orteguian theory is a state of the art issue and aims to review the controversial idea of deshumanization of art.

Key Words: José Ortega y Gasset. Ramón Gómez de la Serna. Greguería. Metaphor. Deshumanization of art. 


\section{INTRODUCCIÓN}

En diciembre de 2008, la Revista de Occidente publicaba un artículo de loana Zlotescu, editora en Galaxia Gutenberg de las obras completas de Ramón Gómez de la Serna, en el que, tomando como referencia el ingente texto autobiográfico Automoribundia, advertía de la intertextualidad que comunica algunas de sus obras con otras de Ortega y Gasset. La autora va aún más allá cuando habla no solo de las "coincidencias profundas de sus opiniones" tanto en política, como en arte y literatura, sino de cómo "La obra de los dos va en paralelo [...] y entre los dos se crea el gran texto de la modernidad española" (Zlotescu, 2008b: 57). De esa intertextualidad, Zlotescu escoge algunos presupuestos de La deshumanización del arte que pone brevemente en relación con ideas vertidas por Ramón Gómez de la Serna en 1909 en "El concepto de la nueva literatura". Cinco años antes se había anticipado a esta idea Rueda Garrote (2003) cuando, al hablar sobre la teoría de las vanguardias, situaba a Gómez de la Serna como precursor de muchas de las ideas orteguianas.

El propio Ramón, en una entrevista a Antonio Obregón, que él mismo recoge en Automoribundia, explicaba: “Don José Ortega y Gasset ha subido varias veces a mi torreón. Allí confesaba él que fue donde vio claro el secreto del arte moderno [...] Mi alegría mayor fue verle comprender la hilaridad de todo aquello" (OC, XX: 573). Siempre se consideró "su banderillero", aquel que abrió camino a sus teorías estéticas e incluso a su concepción vitalista del mundo. Sin embargo, según acreditan numerosas biografías y tantos artículos sobradamente documentados (Vega Díaz, 1984; García, 2007; Zlotescu, 2008b), lo hizo desde una inequívoca admiración por el filósofo, a quien consideraba “Ese maestro único, al que seguimos sin el rubor que da todo mal proselitismo" porque "allí donde don José se sienta se entiende todo y se puede decir todo"1.

Mario Paoletti (2009), un año después del artículo citado de loana Zlotescu, sacaba a la luz, en la misma Revista de Occidente, una selección de 59 greguerías marcadas en rojo en un ejemplar de Greguerías escogidas $(1926)^{2}$ de la biblioteca personal de Ortega, hoy custodiada íntegramente por la Fundación Ortega y Gasset-Marañón, en el que reza la siguiente dedicatoria: "Para mi muy admirado y muy querido D. José Ortega y Gasset. Toda gratitud y toda fé". Paoletti no explicita, sin embargo, que el lápiz rojo de Ortega se sirvió de diferentes signos anotados al margen: barra horizontal y vertical, doble barra y triple barra vertical, y aspa. Ignora además otro ejemplar, Novísimas greguerías de 1929, en el que aparecen marcadas 78 greguerías, la mayoría con una pequeña aspa (utilizando

1 Cita del texto de bienvenida a Ortega publicado en la revista bonaerense Caras y caretas, el 8 de agosto de 1928, recogido por Carlos García en su artículo "Ramón y Ortega" (2007: 67).

2 El contenido de esta publicación fue incluido en 1927 en Greguerías escogidas: las 636 mejores greguerías de Ramón Gómez de la Serna (Fernández, 2013: 104). 
de manera excepcional la barra horizontal y vertical) en el margen izquierdo y derecho de páginas pares e impares, respectivamente, donde se señalan, además, con el mismo lápiz rojo, algunos fragmentos clave del prólogo ${ }^{3}$. Igual que el anterior, está dedicado por el autor, esta vez: "Para mi muy querido y admirado Don José Ortega y Gasset, su señoroso creyente. Ramón".

Además de constatar la admiración de Gómez de la Serna, estos hallazgos ponen de relieve, en un sentido recíproco, que Ortega se tomó particularmente en serio su reflexión — dando lugar a una sencilla pero indudable discriminación, quizá cuantitativa o quizá cualitativa - sobre las breves composiciones ramonianas. Tal vez debido al interés que le suscitaba el uso de la metáfora, que tantos autores consideran fundamento de la greguería (Camón Aznar, Gaspar Gómez de la Serna, Richard L. Jakson, César Nicolás ${ }^{4}$, etc.), tal vez por la indudable modernidad del género, o por ambas cosas.

Es a partir de la metáfora, donde las coincidencias apuntadas por Zlotescu empiezan a concretarse en el campo de la estética y la teoría literaria. Así lo atestigua también Blanca Bravo Cela (2003) cuando habla de la filiación que une la teoría de uno con la escritura del otro.

Mientras Ortega acuñaba en 1914 la archiconocida definición de la metáfora como "célula bella", que anticipaba la idea estructuralista de la metáfora como sentido y función de la literatura (Wellek y Warren, 1966: 230), Gómez de la Serna afirmaba tajante, en un sentido similar, que "la greguería lo es todo en un libro", el "glóbulo" que otorga vida propia a la literatura (OC, IV: 45-46) y con el tiempo establecería la fórmula: humorismo+metáfora=greguería (OC, VIII: 141). Vinculaba además la metáfora a la naturaleza relativa y cambiante de la modernidad, teniendo muy presente la teoría orteguiana (López-Molina, 2013: 84). En ambos casos, tanto desde la teoría como desde una incesante práctica creativa, se superaba la idea clásica de tropo como mero ornamento para convertirse en instrumento de expresión de la individualidad, capaz de "multiplicar el mundo" (Gómez de la Serna, OC, VIII: 141).

Por otro lado, desde la publicación en 1925 de La deshumanización del arte, tan discutida durante décadas de lecturas erróneas, como ya advirtió en su día Guillermo de Torre (1956: 85), parece que asistimos por fin a una lenta pero evidente apertura de miras en lo que a la teoría orteguiana del estilo se refiere. Tras los primeros vínculos establecidos con la estilística (Sánchez Reboredo, 1984) o con el formalismo ruso (La

3 El texto inicial del prólogo escrito en 1917 fue la base de constantes reelaboraciones hasta su versión definitiva en 1962, y por lo tanto, el de 1929 es una de las muchas versiones que forman parte de un eje común (Fernández, 2013: 107).

4 En su obra Ramón y la Greguería (1988: 43) el autor la define como "una compleja interacción entre los polos de la metáfora y la metonimia", destacando la importancia de las relaciones de contigüidad. 
Rubia Prado, 1998), la crítica ha llegado a definir la estrecha relación de la teoría de la metáfora de Ortega con Ricoeur (Domingo Moratalla, 2003).

Tanto si el torreón ramoniano fue la verdadera inspiración de Ortega a la hora de desarrollar sus ideas sobre el arte y la literatura, como si fue su verificación, creemos que en ese camino abierto hacia la reubicación de la propuesta estética orteguiana, comienza a resultar imprescindible su estudio contrastado, en clave dialéctica y dialógica, con la obra de Ramón Gómez de la Serna. Ambos lideraron la encarnizada lucha contra el positivismo en España desde el relativismo moderno, y compartieron una voluntad inagotable de autenticidad, espontaneidad y trascendencia. Por otro lado, la capacidad del autor de greguerías de generar nuevos puntos de vista en todo lo que toca, permeabiliza e impregna la teoría orteguiana, abocada desde el principio a hallar en el "ramonismo" la clave de su gran anhelo personal: definir una posición activa para la cultura española dentro de la modernidad.

Ramón Gómez de la Serna es así el único autor español citado por Ortega como ejemplo expreso del arte nuevo en La deshumanización del arte (OC, III: 866). Ni Baroja, ni Azorín, ni ninguno de los autores de la Generación anterior, ni siquiera Valle Inclán, merecieron semejante privilegio en el fastuoso entramado de la modernidad. Tampoco autores como Miró o Pérez de Ayala, máximos representantes de la vanguardia española, y a quienes Ortega dedicó muchas líneas, en comparación con las que dedicó a Ramón. Sus obras jamás motivaron un artículo, ni siquiera una reseña, y sin embargo, fueron leídas en profundidad por el filósofo, e incluso anotadas.

Nuestra intención aquí es adentrarnos en esa lectura permitiendo un análisis en doble dirección de la idea de estilo que confluye en ambos autores. Creemos que las greguerías discriminadas por Ortega, cuanto menos, debieron resultar inspiradoras, enriqueciendo su percepción del fenómeno estético desde una fertilidad sin precedentes en el uso de la metáfora. Partiendo de una breve selección de esas 137 marcas, esperamos también arrojar algo de luz sobre la controvertida idea de deshumanización del arte.

\section{LA RAZÓN VITAL COMO FUNDAMENTO DE LA REFLEXIÓN ESTÉTICA: EL IMPERATIVO DE ACTUALIDAD EN LA GREGUERÍA}

Como paso previo al reto dialógico que consiste en integrar la teoría orteguiana y la práctica literaria de Ramón Gómez de la Serna, conviene recordar que las aportaciones de Ortega y Gasset, tanto a la historia del pensamiento como a la teoría del arte y la literatura, se desarrollan a partir de su sistema de la razón vital 冈o al menos como intuición previa囚 que posteriormente evolucionaría en razón histórica. 
Lejos de la asistematicidad de la que se ha acusado al filósofo por la dispersión de sus escritos, en un nivel de lectura que mire más allá del fragmentarismo formal, todo en Ortega se entreteje como en un inmenso tapiz, que es esa "gran cosa" que, según Nietzsche, sabe el erizo frente al zorro ${ }^{5}$ y que debe ser tenida en cuenta si se aspira a comprender en profundidad cualquiera de las parcelas de su pensamiento.

La reflexión estética de Ortega no puede por tanto entenderse si no es dentro de su filosofía vitalista (Urrutia, 2006: 19). Desde ella se reclama un arte vital, cuajado de auténtica humanidad, de donde se desprende, como veremos, el mecanismo inevitable de deshumanización o irrealización del objeto estético. Haciendo un paréntesis intencionado sobre La deshumanización del arte, hemos querido rescatar esta reivindicación orteguiana de textos menos contaminados por los prejuicios creados en torno al ensayo de 1925.

Criticaba así Ortega, por ejemplo, a comienzos de la década de los veinte, la última obra de Anatole France por su inmovilismo, a pesar de su evidente perfección formal:

A esta belleza, que aspira sobre todo a ser incorruptible y sin edad, confieso preferir un arte más saturado de vida que se sabe hijo de un tiempo y con él destinado a transcurrir. Ese presunto carácter de eternidad, de incorruptibilidad, de insumisión a los gusanos, solo se logra vaciando la obra de toda entraña viva... (OC, II: 361, la redonda es nuestra).

En un sentido similar, había expresado Ortega años antes, comparando a Machado con Unamuno, que el poeta siempre tiene sobre el filósofo una dimensión de sensualidad (OC, II: 147).

La vida, arrancada de la circunstancia concreta del individuo y en toda su corruptible humanidad, está en la base de todo fenómeno estético. Esta característica, que ha encumbrado la literatura de Gómez de la Serna tras el reconocimiento de tantos autores, desde Calvino a Borges o Cortázar (Zlotescu, 2008a: 40), y que él mismo reclama como “UN ESTADO DE CUERPO" (OC, I: 156), habitualmente ha sido pasada por alto en Ortega, quien, por el contrario, fue identificado con los fríos e intelectuales presupuestos de la poesía pura. A día de hoy, sin embargo, no puede ser pasado por alto que ese arte saturado de vida, en un sentido biológico, que derrocha Ramón, resulta del enorme alcance teórico del epicentro del propio sistema orteguiano: la idea de vida humana como realidad radical.

5 Philip Silver, en su obra Fenomenología y razón vital, incluye una cita de Nietzsche sobre Arquíloco, quien decía: "El zorro sabe muchas cosas, pero el erizo sabe una gran cosa". Para Julián Marías, Ortega "era un erizo cuya gran cosa consistía en que debía aparecer siempre disfrazado de zorro" (Silver, 1978: 143). 
Desde los estudios de Ricardo Senabre (1964), se hizo palpable esa dimensión de sensualidad en el propio estilo de la prosa orteguiana. Porque la existencia del hombre viene marcada por un imperativo de autenticidad que vincula sin remedio el arte a la vida, puesto que ambas resultan creaciones originales que hunden sus raíces en la verdad más humana, concreta y sensible 6 .

La idea de vida humana orteguiana se reconoce así con claridad en el discurso de Gómez de la Serna, que define la propia greguería como correspondencia inmediata a una circunstancia particular:

La Greguería, aunque en eso esté precisamente su corrupción, debe recoger cosas muy locales, muy pasajeras, muy efímeras, porque la corrupción es humana y el arte humano debe gozar y perfeccionarse y descansar en ese corrompimiento (OC, Vl: 48).

También para Gómez de la Serna la vida es esa servidumbre espacio-temporal. La greguería es el género más vital que existe porque recoge cosas"efímeras"—que implican su servidumbre temporal—y "locales"—-determinadas por el espacio concreto-, que dejan en carne viva su esencia corruptible, circunstancial.

Acorde con el contexto finisecular que ambos compartieron, el instante presente representa la existencia en su máxima plenitud y, por lo tanto, es la única verdad del hombre como ser mortal. El imperativo de autenticidad supone, por lo tanto, junto al imperativo de invención, imperativo de actualidad. En 1909, cuando Gómez de la Serna exponía el concepto de la nueva literatura, concebía el minuto "de una manera apoteósica, formidable", porque "lo actual afirma nuestra finitud" y, por lo tanto, afirma la vida. "Somos de nuestro momento, y sería mentir a nuestra naturaleza, aterirla y resabiarla, el creer otra cosa" (OC, I: 168).

La vida, entendida como proyecto en permanente construcción desde el imperativo de actualidad, está contenido en la propia esencia de la greguería, que Gómez de la Serna insiste en definir como "el paso de las horas y de las ráfagas de las cosas a través del alma contemporánea" (OC, VI: 47). La existencia es para ambos problema y caos, y la vida humana resulta del propio caos vertido en la intimidad de cada cual. Contra la autenticidad de la incertidumbre vital operan el logos y la cultura, procesos de abstracción

6 Así lo recoge Ortega en su Prólogo para alemanes: «No podemos ser "hombres de Plutarco", ni "señores feudales", ni "versallescos", ni "jacobinos". O mejor dicho, lo terrible es que podemos intentar serlo, pero que entonces nuestra vida será una mascarada. Toda vida humana tiene que inventarse su propia forma. [...] El imperativo de autenticidad es un imperativo de invención. Por eso la facultad primordial del hombre es la fantasía [...] La vida humana es, por lo pronto, faena poética, invención del personaje que cada cual, que cada época tiene que ser. El hombre es novelista de sí mismo» (OC, IX: 137-38, la cursiva es nuestra). 
que ambos rechazan porque anulan la inmediatez de la vida (Ortega y Gasset, OC, I: 755), adulteran, en definitiva, la única verdad del hombre.

\section{MIRADA Y PERSPECTIVA: UNAS GOTAS DE FENOMENOLOGÍA EN CLAVE RAMONIANA}

El sistema raciovitalista orteguiano encuentra un sólido apoyo en la fenomenología desde el Ensayo de estética a manera de prólogo en 1914 e incluso con anterioridad (Silver, 1978: 17-25). El proceso de asunción de la propia circunstancia consiste en hallar una mirada personal sobre las cosas que se fundamenta en la epojé fenomenológica, al menos como herramienta (Ortega y Gasset, OC, IX: 152-166). Solo tomando conciencia del propio acto de percepción, el individuo puede ser fiel al imperativo de autenticidad necesario para la creación original de una obra de arte, rechazando todo prejuicio impostado y ajeno, y liberándose de la tradición en favor de su punto de vista individual. Lo explica así Ortega en su primer Espectador:

El punto de vista individual me parece el único punto de vista desde el cual puede mirarse el mundo en su verdad [...]

La verdad, lo real, el universo, la vida - como queráis llamarlo- se quiebra en facetas innumerables, en vertientes sin cuento, cada una de las cuales da hacia un individuo. Si este ha sabido ser fiel a su punto de vista, si ha resistido a la eterna seducción de cambiar su retina por otra imaginaria, lo que ve es el aspecto real del mundo.

$Y$ viceversa: cada hombre tiene una misión de verdad. Donde está mi retina no está otra; lo que de la realidad ve mi pupila no lo ve otra. Somos insustituibles, somos necesarios (OC, II: 162-3).

Siete años antes, Gómez de la Serna había defendido la misma visión perspectivista y circunstancial del mundo, que se extendió a toda su generación:

El paisaje de ojos para fuera no existe. Figurémonos un paisaje en un espejo, sin unos ojos que lo observen y un estado de ánimo que lo particularice. No existe, sencillamente, no existe. No puede existir. Es inconcebible de no estar refractado por la sensibilidad según sus características y su acuerdo del momento (OC, I: 156).

La verdad como perspectiva representa el fundamento de la modernidad, desde el que nacen por lo tanto sus necesidades estéticas. El hombre moderno, como dice Gómez 
de la Serna, habrá de aceptar "con ilusión" la relatividad de lo real. De ahí que Ortega tratara de presentar a Einstein como el correlato científico del nuevo sentido de verdad en Filosofía (Gracia, 2014). Las consecuencias resultan obvias en el campo de la estética, pues será el punto de vista particular del artista lo que dé carta de naturaleza a la obra de arte.

Cuando Ortega habla sobre Góngora en 1927, confiere al poeta"una facultad superior de intuición mágica" que consiste en "mirar el universo con el ojo ígneo de Polifemo" (OC, IV: 587). El poeta es, primero, intuición, y en última instancia, mirada, una perspectiva bajo la que bulle su sensibilidad artística.

El propio Ramón se atribuyó a sí mismo la identidad fundamental de "mirador". Para él, la obra de arte, en tanto que aspira a ser original, única e irrepetible, requiere "enfocar las cosas en ángulo, no demasiado de frente o demasiado a todo lo ancho, y jde ninguna manera! en panorama [...] el misterio de que una cosa literaria resulte consiste en que estén bien hallados los ángulos" (OC, XVI: 302). Por ello, todo lo que reduzca las distintas perspectivas posibles es "monstruoso", y solo en la multiplicidad adquiere la realidad dimensión de profundidad y capacidad de perpetuarse en el tiempo.

Tomando la perspectiva del artista como punto de partida, fue el propio Ortega quien primero identificó la mirada única de Gómez de la Serna cuando lo incluyó en La deshumanización del arte como un autor vinculado al infrarrealismo. Compartía así cartel con Joyce y Proust en el desarrollo de esa nueva estética, que Ortega definía así:

[...]Basta con invertir la jerarquía, hacer un arte donde aparezcan en primer plano, destacados con aire monumental, los mínimos sucesos de la vida [...] una inmersión bajo el nivel de la perspectiva natural [...] El procedimiento consiste sencillamente en hacer protagonistas del drama vital los barrios bajos de la atención (Ortega y Gasset, OC, III: 866, la redonda es nuestra) $)^{7}$.

Junto con el relativismo de lo real, el juego y la inversión de valores se sitúan en la base de la modernidad en evidente relación con el perspectivismo y la fenomenología. Considerar serio lo trivial y trivializar lo serio es una cuestión de "atención, plano o perspectiva", pero al mismo tiempo responde a la necesidad de romper con el positivismo y el tradicionalismo. La epojé fenomenológica se tiñe así de voluntad nietzcheana y, por lo tanto, de rebeldía y ejercicio innegociable de la libertad individual.

7 Posteriormente la crítica ha estudiado las relaciones establecidas por Gómez de la Serna desde una intención igualadora. Es en la ausencia de valoración, no tanto en la inversión, donde reside el contrapunto subversivo de la perspectiva ramoniana (Nicolás, 1988). 
Ortega y Gasset, desde esa intención beligerante que imprimió en La deshumanización del arte, dedicó todo un capítulo a "la intrascendencia del arte". Mientras que Gómez de la Serna había señalado ya en 1909 lo lúdico como esencia del fenómeno estético: "El arte es el juego de los siglos y el último jugar ha sido a quien escamoteaba más la realidad" (OC, XVI: 307), y en 1931 definía el Humorismo como "función vital" y "sentido profundo" de toda obra de arte (OC, XVI: 454), pues"no se puede considerar artístico nada de la realidad que no alcance su desvanecimiento en lo irreal, su muerte en el idéntico absurdo" (OC, XVI: 619).

El juego, la subversión y el absurdo funcionan también para Gómez de la Serna como la epojé o suspensión de la sensación de realidad, que hace posible la apertura hacia múltiples puntos de vista desdeñados por la lógica y la costumbre.

En las greguerías que Ortega y Gasset marcó en los ejemplares de su biblioteca hallamos materializada esa mirada única de Gómez de la Serna que Ortega catalogó de infrarrealista. No solo como perspectiva original fundamentada en el "desvanecimiento de lo real en lo irreal", sino como búsqueda inagotable en sí misma de nuevas miradas emancipadoras e infiltradas de actualidad. Es perspectiva fenomenológica a la vez que proceso vital, circunstancial.

Ramón identifica simples objetos: la chimenea, el aro o el ventilador, con fórmulas geométricas, o razones religiosas y casi metafísicas, provocando el desconcierto necesario que cuestiona nuestra percepción habitual:

Hay en los paisajes una casa en que se fabrican las nubes de la tarde, que expide por su chimenea... Es su misteriosa misión en ese paisaje (con raya vertical, 1926).

La niña con el aro en la mano va al jardín como al colegio jugando con la circunferencia y la secante (con raya horizontal, 1926).

Los ventiladores rotativos que reparten su bendición papal por toda la sala parecen decir: "Ego te absolvo de calorem tuum" (con raya horizontal, 1926).

El efecto chocante se intensifica en algunos casos, cuando a través de la disolución de una situación real cotidiana en el absurdo, la greguería se carga de trascendencia:

Hay un señor que pide permiso para llevarse una de las sillas que hacen tertulia alrededor de nuestra mesa... Accedemos siempre con amabilidad, pero otra cosa nos queda adentro (...) No tomaba nada porque no había querido, pero era como nuestra sobrina y nos da pena que nos la quiten (con raya vertical, 1926). 
La personificación de la silla proyecta sobre la ausencia del objeto un vacío existencial inesperado, que vulnera nuestra percepción habitual reconduciéndonos a un sentimiento universal impropio, como es la soledad. La espiritualización de objetos terrenales resulta un procedimiento habitual en la greguería: "El día del perdón y del juicio final las estrellas de mar subirán al cielo" (con raya horizontal, 1926) o "Sobre los campos iluminados desigualmente por la luna, parece que hay puesta a secar una gran cantidad de ropa blanca, sábanas, camisas y calzoncillos de luna" (con raya vertical, 1926). El mismo efecto se logra por analogía en el caso siguiente: "Lo que da más tristeza en la vida son las conferencias sin nadie y los ensayos de órgano" (con aspa, 1929). El sentimiento de tristeza con el que se identifican ambas situaciones distorsiona su cotidianeidad y las eleva a otro plano.

Mayor impacto sobre lo trascendente tiene la inversión de jerarquías en sentido contrario. El autor no se limita, como dice Ortega, a elevar lo cotidiano, sino que degrada lo trascendente, por ejemplo, el arte, hasta reducirlo todo a un nivel neutro de percepción que César Nicolás denomina "sorprendente ecuación igualadora" (1988: 20, 95):

Los violines que el artista afina dejan sembrado el aire de pelillos musicales" (con raya horizontal, 1926).

Los contrabajos siempre parece que están dando azotes a los violonchelos" (con aspa, 1929).

Lo que más prueba el verano es ver el revés de los operadores de cinematógrafo, abierta su cabina, en mangas de camisa junto a la bitácora, junto a la ametralladora eléctrica" (con raya vertical, 1926).

Es así como la propia mirada se coloca en primer plano y se constata un grado superior de rebeldía.

La habilidad de hacer protagonista de sí mismo al propio acto de percepción alcanza el grado de reivindicación en el ejemplo siguiente, donde la mirada forma parte del desarrollo de la greguería y adquiere así la naturaleza viva y corpórea de la propia mirada ramoniana: "Íbamos metiendo el diente de la mirada en todos los escaparates cuando de pronto tropezamos con una tienda de maquinaria: '¡Caray!', y pasamos de largo con la mirada mellada para un largo rato" (con aspa, 1929). En una insolente y nueva vuelta de tuerca, la inversión se realiza sobre la idea misma de perspectiva, jugando con los presupuestos fenomenológicos más allá de la Filosofía.

Tanto los "calzoncillos de luna", como la "ametralladora eléctrica" o la "mirada mellada" se nos ofrecen así como lo que son, miradas que no fueron nunca antes, constitutivas de una identidad original que se atreve, desde la conciencia y la lucidez de su propio proceso creativo, a incluir la propia mirada como parte imprescindible del juego. Representan esa 
nueva perspectiva, necesariamente subversiva, que asume sin prejuicios su circunstancia en la modernidad española. En su esencia de proceso y de búsqueda es, además, el primer paso para alcanzar la consecución definitiva de lo artístico en lo sublime ${ }^{8}$.

Gómez de la Serna tuvo siempre presente esta trayectoria y su objetivo último. Por eso, el Humorismo es "lo terrible sublime" y "lo burlón sublime", y tiene la elevada misión de provocar "una nueva movimentación de la vida [...] un salirse de sí por montañas rusas que se dirigen a mundos lunares y como marginales del mundo". Pues "cree como nadie en la estética suprema, más allá de la estética, entrevisión solo a través de cielos rotos" (OC, XVI: 455, 466).

\section{EL ESTILO DESHUMANIZADO O LA MATERIALIZACIÓN DE LO HUMANO}

Desde esta comprensión del mundo como realidad relativa que compartieron estos dos autores, la literatura y el arte representan una perspectiva diferencial. El artista debe ver lo que otros no ven, ejercer su libertad de percepción, pero al mismo tiempo debe ser capaz de dar forma a esa mirada. Solo desde su existencia material y corpórea puede un objeto ser aprehendido por un receptor, imprescindible en todo proceso estético fundamentado en la fenomenología. Por lo tanto, la perspectiva original del artista, abstracta por naturaleza, necesita su materialización en el estilo.

Ortega define en 1925 esa concreción formal en términos de deformación y estrangulación de lo real, esto es, de quiebra de su aspecto humano o"deshumanización"9, cuyo objetivo último es la "trituración" del aspecto externo de los objetos.

Guillermo de Torre advertía ya en 1956 (1956: 83) de que remontándonos hasta 1910 podemos hallar en Adán en el Paraíso la misma necesidad de "desarticular la naturaleza para articular la forma estética" (Ortega y Gasset, OC, Il: 70). Y si forzamos aún más el límite temporal encontraremos que es la misma idea que se esconde tras el juicio de "perlas prodigiosamente contrahechas" con que Ortega había valorado el estilo de Valle Inclán

8 César Nicolás incluye a Gómez de la Serna en esa lista privilegiada de autores, desde Pirandello a Octavio Paz, que tratan el humor como "un complejo fenómeno que envuelve valores críticos, emotivos, poéticos, estéticos y filosóficos de tal trascendencia" que se constituyen "en una constante semiótica que ha acompañado siempre a las grandes manifestaciones artísticas o literarias" (1988: 110).

9 Explica así Ortega el concepto de deshumanización en uno de los fragmentos más explícitos y polémicos de La deshumanización del arte: "[El artista] se ha propuesto denodadamente deformarla [la realidad], romper su aspecto humano, deshumanizarla [...] En su fuga de lo humano no le importa tanto el término ad quem, la fauna heteróclita a que llega, como el término a quo, el aspecto humano que destruye. [Se trata de pintar] una casa que conserve de tal lo estrictamente necesario para que asistamos a su metamorfosis [...] El placer estético para el artista nuevo emana de ese triunfo sobre lo humano; por eso es preciso concretar la victoria y presentar en cada caso la víctima estrangulada" (OC, III: 859). 
en 1904 (OC, I: 25), precisamente por buscar puntos de vista que se fundamentan en los lados o aristas de la realidad. Se anticipaba esta vez Ortega al discurso de Gómez de la Serna sobre la necesidad de evitar las visiones panorámicas.

Pero no es hasta el Ensayo de estética a manera de prólogo publicado en 1914 cuando se desgrana de manera rigurosa y completa la teoría sobre el estilo y el fenómeno estético que se trasladaría luego a La deshumanización del arte. Aquí, igual que en 1910, se mantiene la tesis de que "el arte es esencialmente irrealización" (OC, I: 678). El centro del ensayo era, sin embargo, el objeto estético como "objeto ejecutivo". La “irrealización"o "desarticulación" no es sino una implicación más dentro de una teoría amplia y compleja fundada en la fenomenología, con una voluntad idealista de sistematización que la rebasa. Desde esta posición se acerca sin titubeos a un estructuralismo que supera en una fecha tan temprana el gran lastre de las escuelas formalistas, el ámbito antropológico e imaginario (García Berrio y Hernández Fernández, 2012: 72), o lo que para Ortega sería la propia identidad circunstancial del hombre.

El objeto estético aparece definido en 1914 como el único objeto que se presenta en pleno desarrollo de su propia intimidad, esto es "como ejecutándose" en su "absoluta presencia" (Ortega y Gasset, OC, I: 671). Esto ocurre porque el arte, como medio de expresión, se diferencia sustancialmente del lenguaje como comunicación:

El arte no es solo una actividad de expresión de tal suerte que lo expresado, bien que inexpreso, existiera previamente como realidad. [...] De modo que el sentimiento es en el arte también signo, medio expresivo, no lo expresado, material para una nueva corporeidad sui generis. [...]

Lo que ocurre es que la función expresiva del idioma se limita a expresar con unas imágenes (las sonoras o visuales de las palabras) otras imágenes, las cosas, las personas, las situaciones, y el arte, en cambio, us a de los sentimientos ejecutivos como medios de expresión y merced a ello da a lo expresado el carácter de estarse ejecutando (OC, I: 677-678).

Desde el estructuralismo y la semiótica, esta definición del arte se identificaría con un sistema de signos que se sirve del plano del contenido del lenguaje habitual como función comunicativa, utilizando como significante aquello que es significado en la lengua comunicativa, por ejemplo, el sentimiento. $Y$ es este peculiar sistema, cercano, con todos los matices que se quiera, a la semiótica connotativa, lo que otorga a la obra su particularidad de objeto estético: el de la ejecución de su propia intimidad, de manera que "si el idioma nos habla de las cosas, alude a ellas simplemente, el arte las efectúa" (Ortega y Gasset, OC, I: 678). Para Ortega, esta ejecutividad se identifica con la intimidad 
en su idea de vida como realidad radical, es decir, con el máximo nivel de concreción y sensualidad. Por eso insiste otra vez en oponer el arte a toda abstracción:

No digo - icuidado! - que la obra de arte nos descubra el secreto de la vida y el ser: sí digo que la obra de arte nos agrada con ese peculiar goce que llamamos estético, por parecernos que nos hace patente la intimidad de las cosas, su realidad ejecutiva —-frente a quien las otras noticias de la ciencia parecen meros esquemas, remotas alusiones, sombras y símbolos (OC, I: 670672).

De este modo, el objeto estético es apariencia de realidad vivida que se concreta en su forma material (líneas, colores, palabras...), pero que en virtud de ese uso significante de los sentimientos, tiene la capacidad de evocar su intimidad.

Para lograr esa transubstanciación necesaria de los significados habituales (imágenes de cosas, personas o sentimientos) en material significante, es necesario que la palabra o el enunciado "entre en erupción, se ponga en actividad, adquiera un valor verbal" (Ortega y Gasset, OC, I: 676). Debe hacerse patente su "valor sentimental", que es donde reside precisamente su capacidad ejecutiva o connotativa. En tanto que "Toda imagen objetiva, al entrar en nuestra conciencia o partir de ella, produce una reacción subjetiva", Ortega denomina "sentimiento" a lo que esa imagen es como "estado ejecutivo mío" o "actuación de mi yo" (OC, I: 676). En otras palabras, el "valor sentimental" es el efecto que produce en el sujeto todo acto de percepción sobre un objeto como algo actuado por él, del que, sin embargo, el propio sujeto no suele ser consciente.

Por eso el objeto estético no puede existir como tal si se percibe como realidad externa pasiva, ni tampoco, en un sentido romántico, como emoción exclusiva del receptor. La única manera de lograr la ejecutividad del objeto es llamando la atención sobre el propio acto de percepción del artista, haciendo evidente, desde la deformación del original, su actuación sobre el objeto como objeto percibido. De ahí arranca su capacidad de connotar, que consiste en evocar la mirada individual del artista reproduciendo el efímero y vivísimo instante de su interacción activa con el objeto. Por eso en la greguería anteriormente comentada los espectadores "meten el diente de la mirada en todos los escaparates" a la vez que el objeto observado, la maquinaria, devuelve su mordida haciendo mella en el propio acto de percepción.

La desarticulación o trituración de la imagen real externa como tal, es decir, la deshumanización del arte, funciona por tanto como suspensión o epojé fenomenológica. Su misión consiste precisamente en poner en crisis la idea del objeto como realidad externa al sujeto, de manera que el acto de percepción se reivindique desde la consciencia y el objeto estético quede así "efectuado". 
De aquí pueden inferirse las dos dimensiones fundamentales de la obra de arte como signo, la forma material significante, en la que reside la capacidad de efectuar o connotar, y el significado efectuado, que responde a la perspectiva original del artista. Ambas dimensiones resultan para Ortega imprescindibles a la vez que interdependientes en una unidad sin fisuras. En un artículo de 1929 titulado "Sobre la expresión: fenómeno cósmico", explica Ortega cómo"la carne es expresión, es símbolo patente de una realidad latente" más profunda (OC, II: 681) que, como en una simbiosis irrenunciable, necesita verificarse en la materia.

Algunas de las greguerías que Ortega marcó en rojo en los ejemplares de su biblioteca permiten indagar en esta cuestión, pues la inversión de la perspectiva ramoniana se actualiza también desde la experimentación verbal (Nicolás, 1988: 97-98) realzando la materialidad del signo: "Erudición debería tener hache. No se sabe cómo una cosa tan seria está desprovista de gorrete" (con raya horizontal, 1926); “¿Error se escribe con hache?, es una pregunta que surge muchas veces, como temiendo cometer un pecado de horripilancia..." (con aspa, 1929). El estado de cuerpo, la sensualidad orgánica, se manifiesta en el significante hasta el punto de otorgar sexualidad a las palabras: "El primer encuentro con algunas palabras fue inolvidable, como el noviazgo con aquellas jovencitas cuyos senos muy apuntados rozamos con el brazo... ¡Noviazgo con Añoranza, Lembranza, Ofrenda, Evocación, Morbidez, etc., etc!" (con raya vertical, 1926).

Por un lado, resulta imprescindible realzar el material significante y su valor verbal, pero por el otro, este debe efectuar la intimidad del artista, su perspectiva individual y su actitud ante el mundo (Sánchez Reboredo, 1984: 194), o de lo contrario, quedará reducido a un ornamento vacío. Ya en 1910 establecía Ortega el peligro de una literatura convertida en "superflua retórica" (Inman Fox ed., 1987: 121-122). En este sentido, "el don más sublime" es "construir algo que no sea copia de lo "natural"y que, sin embargo posea alguna sustantividad" (Ortega y Gasset, OC, III: 859).

El estilo es, por tanto, "La peculiar manera que en cada poeta hay de desrealizar las cosas", donde queda particularizada su mirada. A través de un proceso de desarticulación formal que permite su ejecutividad, lo efectuado ha de obedecer a la propia identidad: la vida humana como realidad radical. La deshumanización del arte nace así como respuesta a la más acuciante de las necesidades humanas, reivindicar su posición vital, concretar su humanidad. Por eso el Ensayo de estética de 1914 concluye con la rotunda afirmación orteguiana: “El estilo es el hombre” (OC, I: 678).

No se nos ocurre en el panorama español mejor ejemplo de artista que pueda identificarse hasta ese punto con su estilo literario que Ramón Gómez de la Serna. Alejado descaradamente de la copia del natural, se carga en cambio de "la sustantividad" que Ortega reclama para toda creación original. 
loana Zlotescu, en su Prólogo a las Obras Completas de Gómez de la Serna, reproduce una cita de Ángel del Río que nos resulta muy reveladora al respecto:

Para expresarse crea todo un estilo (...) cuya unidad es la greguería... Tan original y sin precedentes es todo ello, que para designar esta literatura especial ha habido necesidad de inventar una palabra tomada de su nombre: ramonismo" (1996: 18).

\section{LA METÁFORA EN ORTEGA Y SU PROYECCIÓN EN LA GREGUERÍA}

Más allá de representar a un nivel abstracto la idea de estilo propuesta por Ortega, Gómez de la Serna explotó hasta las últimas consecuencias el principal mecanismo que permite la deliberada actualización de esas formas desarticuladas, así como su proyección universal: la metáfora. Esta es átomo constitutivo del estilo para Ortega y fundamento de la greguería para Gómez de la Serna.

En un sentido similar a la proyección que César Nicolás (1988) realizó de la función poética de Jakobson sobre el género inventado por Ramón, creemos que la greguería ofrece un modelo práctico desde el que leer la teoría orteguiana de la metáfora, aportando nuevos puntos de vista al ejemplo de López Picó utilizado en el Ensayo de estética en $1914^{10}$. Es nuestra intención profundizar en la greguería como proceso en el que se desarrollan y reivindican todas las peculiaridades de la reflexión orteguiana, a través de una metaforización consciente de las distintas fases del propio proceso metafórico. Esta nueva lectura contribuye además a constatar los vínculos establecidos con la metáfora viva de Ricoeur (Domingo Moratalla, 2003).

Como ejemplo inicial, Ortega señaló con un aspa en 1929 la siguiente greguería: "Las metáforas acuden a los terrones, y si el terrón está mojado en ron, mejor que mejor", donde se asocia la metáfora al enriquecimiento e impregnación de los objetos.

\subsection{LA GREGUERÍA DESARTICULADA}

La idea de metáfora como procedimiento estético fundamental implica para Ortega, en primer lugar, la desarticulación de la imagen externa de la realidad que permite la ejecutividad del objeto estético o su capacidad connotativa. En su afán por fundamentar su idea de estilo en la fenomenología y en la incipiente idea de vida humana como realidad

10 Ortega ilustra en 1914 su teoría con esta sencilla metáfora en francés original: el ciprés és com l'espectre d'una flama morta (OC, I: 673), primando así la claridad al servicio de una finalidad didáctica. 
radical, Ortega revolucionó la idea de metáfora heredada de la retórica tradicional. Abandonaba la consideración de simple ornamento desde un sólido argumentario en "Las dos grandes metáforas" y ya en 1914 hacía depender el valor estético del tropo en la contradicción, no en la semejanza: "Donde la identificación real se verifica no hay metáfora. En esta vive la conciencia clara de la no-identidad" (OC, I: 674). Por eso Domingo Moratalla (2003) nos conduce a Ricoeur y su idea de la "impertinencia semántica" entre la interpretación literal del enunciado y su sentido metafórico. Según Ricoeur, tras la imposibilidad de concebir el enunciado literalmente desde la lógica y la posibilidad de una interpretación alternativa desde la imaginación, se genera una tensión verbal, que es el fundamento de "la metáfora viva". Dicha vitalidad, efectivamente, parece remitir a la capacidad de mostrar la propia intimidad como "ejecutándose".

Ese conflicto entre las dos posibles interpretaciones del enunciado tendría para Ortega, como primera función, perturbar nuestra visión "natural" de los objetos implicados, "libertarnos (de ellos) como realidad visual y física" (OC, I: 674). De ahí que en el Ensayo de estética se recurra al ejemplo del poeta védico, quien compara siempre dos realidades poniendo de relieve lo que la una no es respecto a la otra (OC, I: 675; OC, II: 509). La "impertinencia semántica" provoca así, desde la tensión de la no identidad, la disolución de nuestra percepción habitual de lo real como externo al sujeto.

Entre las greguerías marcadas por Ortega se propone esta misma estructura conflictiva: "No es la esfera de los relojes. Es la córnea de los relojes" (con raya vertical, 1926), donde a la vez que "corrige" el nombre dado desde el uso habitual del lenguaje, reproduce en su enunciado el mecanismo de "Las dos grandes metáforas". La aparente identidad total de los dos objetos (la esfera del reloj y la córnea ocular, en este caso) aparece sugerida desde una identidad parcial y abstracta: la forma esférica, de manera que el receptor percibe la inequívoca falsedad de dicha relación, que va "más allá de su límite verídico" (OC, II: 510). El valor poético de la figura se genera precisamente al poner de manifiesto lo que la córnea no tiene de esférico, por ejemplo, su esencia biológica, la humedad, la secreción, ese "estado de cuerpo" que imprime la mirada original del autor.

Por otro lado, frente a la semejanza evidente entre la forma del ciprés y la silueta de una llama en el ejemplo de López Picó, o la esfera del reloj y la córnea, que el mismo Ortega denomina "insignificante observación geométrica" (OC, I: 674), la metáfora implícita en muchas greguerías pone en conflicto realidades distantes, por lo que la tensión verbal se hace más evidente. Estarían más cerca de lo que Carlos Bousoño (1977: 65) reclama para que la interpretación del enunciado metafórico desde la imaginación adquiera preeminencia respecto a la lógica. Tienden así a una estética moderna, puesto que se cuestiona con rebeldía la percepción habitual-racional, sin llegar a la irracionalidad de la imagen surrealista pero sentando importantes precedentes (Nicolás, 1988: 134). 
Si observamos, por ejemplo: "Por la pared y por el techo pasó la golondrina luminosa de un espejo" (con raya vertical, 1926), la tensión verbal se produciría ahora desde una dificultad mayor para identificar el reflejo del cristal con una golondrina. La golondrina no puede ser, de hecho, el reflejo luminoso, pues aunque el adjetivo se cierne sobre ella en una suerte de "adjetivo traslaticio" clásico (Wellek y Warren, 1966: 231) este subrayaría la propia impertinencia añadiendo una figura de contigüidad a la metáfora. Se fuerza por lo tanto al receptor a buscar una semejanza que ya no es tan evidente como la forma esférica, y que va desde el acto de volar a lo más abstracto, como la fugacidad o la belleza. Desde la ambigüedad de la desemejanza se abre así un amplio abanico de perspectivas que obliga al receptor, ahora desde la imaginación, a entrar en contacto con la mirada ramoniana y a profundizar en su propia experiencia.

La posible semejanza inicial es para Ortega, por lo tanto, el pretexto que nos lleva a un plano imaginado donde ambas realidades se desfiguran. Reloj y córnea, reflejo y golondrina, se han desintegrado como realidades dadas, han sido "aniquiladas en lo que son como imágenes reales" (OC, I: 675), pasando a formar parte del acto de percepción de un sujeto, alcanzando su lugar sentimental, único espacio (virtual) en el que se permite, como veremos, su integración en una sola realidad.

La desarticulación o deshumanización de las cosas como primera fase del proceso metafórico, está en la base de las greguerías hasta tal punto que se hace patente en muchas de ellas, no solo desde el estilo. Es el caso, por ejemplo, de "La jirafa es un caballo alargado por la curiosidad" (con raya horizontal, 1926), o "Cuando llegan los atletas a la estación de término se inclina toda la ciudad por ese lado" (con raya horizontal, 1926). El alargamiento y la inclinación son deformaciones del plano real en las que, a su vez, se fundamenta la metáfora. Desarticulan, por lo tanto, de un modo explícito, la percepción habitual de la realidad. La metáfora aquí no consiste en un simple desvío de la norma lingüística, como insiste Bousoño (1977) para rebatir la teoría orteguiana, implica además una deformación de la imagen real que se fuerza a sí misma a trascender todos los planos del enunciado metafórico. En este sentido, se reproduce en un nivel estético la idea orteguiana del signo ejecutivo o connotativo. Aquí, la nueva realidad conquistada significa la propia deformación llevada a cabo desde la forma, invitando así a interpretar que la ejecutividad del objeto estético se desarrolla en el mismo plano existencial del objeto físico: el acto de percepción del sujeto.

También encontramos en las greguerías el valor verbal que reclama Ortega para que el objeto se efectúe, asociado a la deformación de la realidad externa. En ocasiones, la "entrada en erupción" de las palabras se orienta, además, hacia una perspectiva nihilista más subversiva, como: "El silencio de la madrugada barre las campanas caídas de los tranvías" (con raya vertical, 1926) o "En la hora de la siesta, en que las mecedoras se mueven con afán insistente, parece que trillan, que la faena es trillar el grano de los 
minutos" (con raya vertical, 1926). Los verbos "barrer y trillar" evidencian, cuanto menos, cierto poder de disminución o aniquilación de lo real. Más evidente son los casos en los que esa aniquilación implica un grado de violencia, como"Cuando un automóvil aplasta un gato se ven rodar por la cuneta dos ojos luminosos como dos gemelos escapados de unos puños" (con aspa, 1929) o "Cuando el aprendizaje de los músicos militares con sus trompetas estraga todo el paisaje y lo echa abajo" (con doble raya vertical, 1926).

En un sentido similar al que Ortega dijo que El Quijote "Ileva infartada dentro de sí la aventura", podría decirse que la greguería lleva infartada la realidad, pues la propia desarticulación necesaria para crear el objeto estético se nutre ahora de sí misma.

\subsection{EMERGE EL LUGAR SENTIMENTAL}

La desarticulación de la imagen de los objetos es únicamente procedimiento, como veíamos, dentro de una teoría mucho más compleja del objeto estético. La metáfora, al desdibujar los contornos de los objetos en cuanto a imágenes reales, abre el camino, en una suerte de segunda fase, hacia una confluencia profunda, estética, más allá de la semejanza superficial inicial, y que es la verdadera, pues resulta de la percepción individual del artista. Lo explica así Ortega en 1914 con la metáfora de López Picó:

Así, aquí el ciprés-llama no es un ciprés real, pero es un nuevo objeto que conserva del árbol físico como el molde mental-molde en que viene a inyectarse una nueva sustancia ajena por completo al ciprés, la materia espectral de una llama muerta. Y, viceversa, la llama abandona sus estrictos límites reales [...] para fluidificarse en un puro molde ideal, en una como tendencia imaginativa $(\mathrm{OC}, 1: 675)$.

Los objetos pueden así existir en el "lugar sentimental", que ya veíamos definido como "la forma yo de ambas", puesto que pasan a pertenecer a mi percepción única de la realidad. En nuestro ejemplo anterior, alcanza así la golondrina, en su desintegración, una "blandura de plasma" que le permite imprimirse, como objeto percibido liberado de sus fronteras físicas, sobre el reflejo. Este acepta su intrusión de igual modo, en tanto que "molde ideal", dando lugar a un nuevo objeto en plena efervescencia, esa "nueva cosa conquistada", que Ortega llamaría reflejo-golondrina (OC, I: 677).

Gómez de la Serna afirma así que la greguería surgió un día "de escepticismo y cansancio" en que su autor mezcló todos los ingredientes de su laboratorio y nació "de su precipitación, de su depuración, de su disolución radical, la Greguería". A partir de ese momento, la greguería se convierte en "flor de todo" (OC, IV: 41-42). Es decir, pura vida a 
partir de la disolución y la mezcla entre sustancias. No parece casual que Ortega señalara al margen este inicio del Prólogo en su ejemplar de Novísimas greguerías de 1929.

Juli Highfill (2008: 29) ya advierte de este "espacio intermedio de articulación" en la greguería, donde se flexibilizan estructuras y conceptos para dar lugar a nuevas relaciones entre los objetos. Desde nuestro planteamiento dialógico, vemos en ese espacio una recreación del lugar sentimental orteguiano.

Así, por ejemplo: "Cuando una bicicleta pasa por lo alto del camino parece que el paisaje se ha puesto lentes" (con raya vertical, 1926) ofrece una posición geográfica exacta para el lugar sentimental. Es justo en lo alto del camino donde la bicicleta y las lentes convergen. Si fueran realidades "reales externas", chocarían, pero al verificarse su lugar sentimental en un punto exacto del plano visual, es ahí donde sus fronteras reales se diluyen, y quedan superpuestas en una nueva realidad bicicleta-lente o "bicicleta sentimental", que el propio sujeto actúa y produce.

El lugar sentimental planteado de manera explícita como espacio físico adquiere numerosas variantes entre las greguerías marcadas por Ortega. Hayamos cierta predilección por el cuerpo femenino, acentuando así la organicidad y ampliando el registro de su poder evocador, desde la sordidez a la belleza, como ocurre en "Las prostitutas tienen el vientre blanco y frío de las lagartijas" (con aspa, 1929). En "Esa perla que cae entre los senos, como señal de las hojas de un libro, es como registro para saber dónde nos habíamos quedado", se superpone, además, otra metáfora con función focalizadora del propio lugar donde la propia metáfora se efectúa (con aspa, 1929).

En ocasiones el lugar sentimental se imprime con rotundidad en un espacio material concreto abierto literalmente con el valor verbal de las palabras: "Hay unos novios que pasan por las calles incrustando a sus novias contra las paredes, taraceando en las tapias, gracias al empuje con que aman, una cenefa de cariátides" (con aspa, 1929). Son las acciones de incrustar y taracear, tras un esfuerzo de manipulación física del espacio preexistente, las que "taladran" la estructura de las paredes para abrir la cenefa donde se funden la pared y las novias.

Una vez más, apelando a lo problemático y cambiante de la mirada ramoniana, hallamos incluso el propio proceso de disolución de contornos transmutado en greguería: "Al entrar en un sitio donde hay mucha gente, en ese momento de abrir la puerta y asomar la cara, no somos ni nosotros mismos ni los otros" (con aspa, 1929). El lugar sentimental se asocia aquí al vano de la puerta, pero la greguería se detiene en el instante "efímero" de la propia confusión de identidades. Se impide así la consecución de una nueva realidad y se subraya el proceso de disolución como tal proceso.

Nos interesa también resaltar los casos en los que se concreta la frontera física que da acceso al lugar de confluencia entre los dos objetos: "... los lloros de los niños traspasan las paredes con clavos que llegan a asomar la punta por el otro lado" (con aspa, 1929), 
donde el lloro-clavo necesita atravesar la pared para consolidarse como nueva realidad percibida. En el mismo sentido encontramos "Cuando en el circo el clown traspasa de un salto el disco de papel de seda, la virginidad de la noche ha quedado rota" (con aspa, 1929). En ambos casos el verbo "traspasar"verifica el acceso al lugar sentimental, separado del mundo real por una frontera explícita, pared y disco de papel, respectivamente. En el segundo caso, sin embargo, el tránsito se hace de manera más violenta y el acceso al lugar sentimental implica un salto descabellado, infinito, de la cotidianeidad del circo a la inmensidad de la noche.

El lugar sentimental se revela aquí, por lo tanto, asociado a la fugitividad del fenómeno estético, cuya existencia impone su huida del mundo real cotidiano. Ocurre de manera evidente en “Nunca se encuentra el cepillo. El cepillo es un milpiés que siempre se escapa del sitio en el que se deja, del sitio en el que debería estar" (con raya vertical, 1926). Aquí Ramón juega incluso con el lugar habitual y lógico, donde "debería estar", pues mientras el cepillo está en su lugar acostumbrado sigue siendo cepillo, y solo cuando "se escapa" del espacio reservado a su imagen real, accede a su propio lugar sentimental. Es el cepillo fugitivo, en su huida de lo usual, el que adquiere la capacidad de fundirse con el milpiés en un mismo sentimiento. Casi parece tener moraleja: solo cuando miramos las cosas desde una perspectiva diferente damos pie al fenómeno estético.

La metáfora, nacida de la circunstancia personal de un individuo, nos ofrece el acceso a su porción del universo a través del lugar sentimental, donde se verifica una nueva perspectiva. En la metáfora adquiere forma la propia vida como realidad radical, igual que la célula o el "glóbulo", Ileva en su núcleo el ADN del estilo, y es, por tanto, unidad mínima individualizadora de la realidad percibida por un sujeto. Gómez de la Serna lleva hasta las últimas consecuencias esta idea, pues su propia mirada se impregna de la sensualidad orgánica del proceso vital. Utiliza por tanto la metáfora desde su capacidad de dar forma a la vida para mostrárnosla en plena efervescencia, haciendo vivir la metáfora en sí. El arte es así fenómeno vivificador como "réplica a lo abstracto" (Nicolás, 1988: 128), en la misma línea en que Ortega contraponía el arte a la cultura.

\subsection{EL ACCESO AL PLANO TRASCENDENTE}

La clave de la impertinencia semántica está en que obliga al sujeto a trasladar su percepción del objeto al único lugar donde es posible una nueva pertinencia predicativa, la imaginación (Domingo Moratalla, 2003). Tras su poder desarticulador, y su concreción del lugar sentimental, este "traslado" sería el paso definitivo hasta llegar a la consagración del objeto estético autónomo y universal. Será “la nueva cosa conquistada”, con capacidad para reescribir la realidad. 
Ortega advierte así de que la metáfora insiste "tercamente" en "proponernos" otra realidad, "y nos empuja a otro mundo donde por lo visto aquella es posible" (OC, I: 675). Es el mundo de la ficción, el único lugar donde las leyes racionales pueden eliminarse para abrir ventanas a otra realidad, la del ciprés-llama, la de la bicicleta-lente, el reflejogolondrina, el Ilanto-clavo, el cepillo-milpiés, etc. La metáfora, por lo tanto, no solo hace posible la epojé y la concreción de la perspectiva vital del artista, sino que hace forzoso el traslado a otro mundo, "distinto del mundo físico y del mundo psicológico", que Ortega llama "el ámbito del mundo estético" (OC, I: 678). Emerge de ella, por lo tanto, una nueva significación que se crea sobre las ruinas previas de la impertinencia semántica (Domingo Moratalla, 2003).

No se trata, al menos para Ortega, únicamente del uso desviado de los nombres hacia una nueva forma de expresar lo real, como defiende Carlos Bousoño (1977), sino de una extensión total de significado y por lo tanto de la realidad misma, de esa función heurística que comparte con Ricoeur y que Iñaki Gabaraín denomina "fuerza creadora o 'energeia" (2003: 60). Ya advertíamos de la fuerte relación de adecuación y dependencia que se establece entre el significante material y lo expresado o sugerido, hasta tal punto que, para Ortega, la expresión de todo signo estético conlleva el descubrimiento de un mundo nuevo con leyes propias que no existe previamente como realidad.

En este sentido, algunas greguerías asimilan el lugar sentimental donde se efectúa el objeto estético a la imaginación, realizando en la práctica el traslado que propone Ortega en su teoría, y metaforizando, una vez más, el propio proceso metafórico: “En el sueño, el perro se parece al león. Es que quizá lo sueña..." (con raya vertical, 1926).

La percepción que cuenta ya no es solo la de Ramón, artista, y nosotros, receptores. El perro es quien mira al león en su sueño, y de ese acto de percepción intrínseco nace la propia metáfora, que fuerza a su vez la semejanza entre perro y león, esta vez en el plano real de emisor y receptor. Se hace patente aquí que el perro-león no es solo una nueva forma de expresión, pues necesita un nuevo mundo en el que poder existir, como ya le ocurría al cepillo-milpiés en su fugitividad, y ese es ahora el mundo de los sueños.

Esta verificación del plano trascendente resulta sin embargo de analogías variables: "Cuando se ahogó ella se escaparon sus senos al cielo, como dos burbujas ideales" (con aspa, 1929). Aquí el mundo donde los senos-burbujas son posibles ya no es el sueño, sino el cielo entendido como el otro mundo, el mundo de los muertos, a la vez que en un sentido platónico, donde además se hace patente el trayecto hacia lo ideal trascendente.

La necesidad de trascender el plano de la mera expresión o el mero desvío de la norma lingüística, hasta el punto de hacer del propio proceso metafórico el argumento de la greguería, vuelve a representar para nosotros una reivindicación de Gómez de la Serna. En consonancia con Ortega, cada nueva pertinencia predicativa creada en la metáfora, supone el ensayo de una nueva manera de estar en el mundo (Domingo 
Moratalla, 2003). Ya sea el mundo de los sueños o el de los muertos, lo importante es que es otro, y apuntala el acceso a una manera distinta de vivir y percibir el primero.

El supuesto "error" orteguiano que basa Carlos Bousoño (1977) en la confusión de fundamentar lo poético en la desarticulación de la realidad y no del propio lenguaje, no surge debido a un enfermizo esteticismo emanado de las artes plásticas, y menos aún en la desvinculación del arte con la vida. Es más bien todo lo contrario, el poder heurístico de la metáfora, su capacidad de descubrir realidades nuevas que tienen lugar en mundos imaginados por sujetos únicos, es consecuencia natural de la propia filosofía orteguiana, de un relativismo que pone en el centro de toda consideración al individuo, al hombre que se salva en su mirada única y al universo como confluencia de infinitas perspectivas.

En la medida en que este mundo revelado por primera vez responde a la única y última verdad del individuo, en este caso Ramón Gómez de la Serna, la lealtad a su propia circunstancia de hombre libre, supera en verdad a toda realidad sensible o conceptual. De la "estética suprema" nace así la "suprema verdad", y solo en ella puede salvarse el individuo, una vez trascendida su circunstancia. Ortega resulta sumamente didáctico cuando explica esta idea ya en 1913:

La belleza no está lejos de las cosas sino en ellas, dentro de ellas, es su última potencia. Toda poesía es poesía de circunstancias, como Goethe dice; lo que Goethe no dice es que la poesía sea circunstancia, que el arte sea vida. [...] Arte y poesía son más que vida, más que circunstancia, son la superación de la vida y de la circunstancia. [...]

El artista tiene que trascender de su época. La obra genial se caracteriza porque nacida de unas circunstancias las anula, las rebosa [...] la poesía arranca de entre lo circunstancial una circunstancia y la dota de eterna actualidad (Ortega y Gasset, Inman Fox ed., 1987: 183-184, la redonda es nuestra).

Es en el mundo nuevo creado por el artista y abierto más allá de las fronteras de lo real utilitario - lugar en el que el perro sueña al león y los senos se convierten en burbujas ideales - donde la vida como circunstancia en Ortega se ve definitivamente superada en la obra de arte. El estilo o la forma no es un impedimento para colocar la vida humana en el centro de la obra de arte. Muy al contrario, la metáfora se convierte en eslabón imprescindible para salvaguardar y perpetuar la vida, entendida como perspectiva, en el mundo estético. 


\section{CONCLUSIÓN}

Los ejemplos de las greguerías que se han utilizado son solo algunos de los que Ortega señaló al margen de los dos ejemplares citados de su biblioteca personal. A partir de ellos hemos querido demostrar la profunda relación que existe entre su teoría del estilo, innovadora entonces y vigente hoy, y la práctica literaria de Ramón Gómez de la Serna. La greguería se presenta así como un correlato de la metáfora descrita por Ortega en 1914 y 1925. Se observa, asimismo, una reivindicación del proceso artístico como tal proceso, al convertir en objeto de la práctica de la greguería, las distintas fases implicadas en la reflexión orteguiana y su propia concepción del signo estético.

La circunstancia de Gómez de la Serna, encallada en la modernidad y en la personalidad española 凶que Ortega definió muy temprano como "una ardiente y perpetua justificación de la sensualidad, de las superficies" (OC, I: 778) $₫$ queda universalizada en un nuevo género, la greguería, donde adquiere por fin valor artístico la esencia de la cultura española. No es casualidad que ambos autores prestaran tanta atención a la metáfora, colocándola como el centro vivo de su literatura, cuando en ella hace residir Ortega el poder de trascender lo concreto y de elevar la sensualidad a un plano imaginario abstracto, en definitiva, de universalizar la circunstancia española.

De este empeño resulta la interpretación fundamental que se hace en este estudio de la metáfora en Ortega. La greguería nos ha permitido reconocer, traducido en material literario, el serpenteante trayecto de ida y vuelta que opera en el seno de la metáfora orteguiana, pues arranca de la vida concreta del individuo y la transporta al lugar sentimental abstracto, que se concreta de nuevo en el estilo para tomar el impulso definitivo hacia su universalización. La implicación de todos los planos del signo estético en la greguería supone actualizar o concretar la propia actualización, de manera que igual que Ortega suele trascender en su escritura el plano teórico, la greguería ramoniana contiene toda una reflexión metaliteraria, capaz de eternizar la teoría del signo ejecutivo, donde las nuevas significaciones se construyen, como en un juego de espejos, desde la propia reivindicación connotativa.

El sistema de la razón vital apoyado en la herramienta fenomenológica se sitúa así como el eje central de las reflexiones estéticas de la modernidad española, que hallamos justamente personificadas en Ramón Gómez de la Serna y Ortega y Gasset. Ambos autores implicaron en su obra teoría y práctica literaria, compartiendo un impulso vitalista sensible a su contexto inmediato y el deseo de un reconocimiento activo de su propia circunstancia. De ahí creemos que nace la vigencia inagotable de sus reflexiones estéticas, que superan algunas de las carencias tradicionales del estructuralismo y entroncan con la idea de metáfora viva. 


\section{REFERENCIAS BIBLIOGRÁFICAS}

BOUSOÑO, C. (1977). "La estética de Ortega: notas de controversia". Cuadernos Hispanoamericanos 322-323, 53-77.

BRAVO CELA, B. (2003). “Gómez de la Serna o la greguería deshumanizadora”. Boletín Ramón 7, 3-5. DOMINGO MORATALLA, T. (2003). "La hermeneútica de la metáfora: de Ortega a Ricoeur".

Espéculo: Revista de Estudios Literarios 24, https://pendientedemigracion.ucm.es/info/ especulo/numero24/ortega.htm/ [17/04/2016].

FERNÁNDEZ, P. (2013). “Nota a la edición”. En Obras completas VIII, Pura Fernández (ed.) y loana Zlotescu (dir.), 103-127. Barcelona: Galaxia Gutenberg.

FOX, I. (1984). "Introducción". En Meditaciones sobre la literatura yel arte, Fox, I. (ed.), 7-40. Madrid: Editorial Castalia.

GABARAÍN, I. (2003). “Notas sobre las ideas de Ortega acerca del lenguaje literario: expresión, desvío, estilo". En El lenguaje de la literatura (1898-1936), Ricardo Senabre Sempere, Ascensión Rivas Hernández e Iñaki Gabaraín (eds.), 59-68. Salamanca: Ediciones Almar. GARCÍA BERRIO, A. y HERNÁNDEZ FERNÁNDEZ, T. (2012). Crítica literaria. Madrid: Cátedra. GARCÍA, C. (2007). “Ramón y Ortega”. Boletín Ramón 14, 64-74.

GÓMEZ DE LA SERNA, R. (1926). Greguerías escogidas. París: Agencia Mundial de librería. (Ejemplar original de la biblioteca personal de Ortega y Gasset) (1929). Novísimas greguerías. Madrid: Ernesto Giménez (Ejemplar original de la biblioteca personal de Ortega y Gasset).

(1996-2014). Obras completas, loana Zlotescu (ed.). Madrid: Galaxia Gutenberg.

GRACIA, J. (2014). José Ortega y Gasset. Barcelona: Taurus y Fundación Juan March.

HIGHFILL, J. (2008). “Comercio metafórico. Las Novísimas greguerías y su circunstancia”. Boletín Ramón 17, 16-32.

LA RUBIA PRADO, F. (1998). “La cuestión del género literario: el ‘Ortega vanguardista' y los formalistas rusos". Anales de la Literatura Española Contemporánea 23, 197-216.

LÓPEZ-MOLINA, L. (2013). “Ramón y la greguería”. En Obras completas VIII, Pura Fernández (ed.), Ioana Zlotescu (dir.), 77-101. Barcelona: Galaxia Gutenberg.

NICOLÁS, C. (1988). Ramón y la Greguería. Cáceres: Publicaciones Universidad de Extremadura / La literatura y el arte/Madrid: Editorial Castalia.

ORTEGA Y GASSET, J. (2004-2010). Obras completas. Madrid: Taurus y Fundación Ortega y Gasset.

PAOLETTI, M. (2009). “Ortega: lector de gregues". Revista de Occidente 336, 5-12.

RUEDA GARROTE, J. F. (2003). “El equilibrio entre la forma, el contenido y la función en el arte nuevo: apuntes sobre la teoría artística y estética en Ramón Gómez de la Serna". Boletín de Arte 24, 287-322. 
SÁNCHEZ REBOREDO, J. (1984). "La noción de estilo literario en Ortega y Gasset". Cuadernos Hispanoamericanos 403-405, 293-298.

SENABRE SEMPERE, R. (1964). Lengua y estilo de Ortega y Gasset. Acta Salmanticensia, Filosofía y Letras, tomo XVIII, núm. 3, Salamanca.

SILVER, P. (1978). Fenomenología y razón vital, génesis de "Meditaciones del Quijote" de Ortega y Gasset. Madrid: Alianza Editorial.

TORRE, G. (1956). “Las ideas estéticas de Ortega”. Sur 241, 79-89.

URRUTIA, J. (2006). “Vitalidad de La deshumanización del arte”. Revista de Occidente 300, 5-22.

VEGA DÍAZ, F. (1984). "La amistad entre Ortega y Ramón Gómez de la Serna". Cuadernos Hispanoamericanos 403-405, 317-328.

WELLEK, R. y WARREN, A. (1966). Teoría literaria. Madrid: Editorial Gredos.

ZLOTESCU, I. (2008a). "Prólogo". En Obras completas I, loana Zlotescu (ed.), 11-43. Barcelona:

Galaxia Gutenberg.

(2008b). "Ramón y Ortega: sesenta años de Automoribundia". Revista de Occidente 331, 39-60.

Recibido el 20 de abril de 2016.

Aceptado el 15 de noviembre de 2016. 
